NBER WORKING PAPER SERIES

\title{
PERSPECTIVES ON TRADE AND STRUCTURAL TRANSFORMATION
}

\author{
George A. Alessandria \\ Robert C. Johnson \\ $\mathrm{Kei}-\mathrm{Mu} \mathrm{Yi}$ \\ Working Paper 28720 \\ http://www.nber.org/papers/w28720 \\ NATIONAL BUREAU OF ECONOMIC RESEARCH \\ 1050 Massachusetts Avenue \\ Cambridge, MA 02138 \\ April 2021
}

We thank Joseph Kaboski, Doug Gollin, and an anonymous reviewer for helpful comments on this paper. This document is an output from the research initiative 'Structural Transformation and Economic Growth' (STEG), a programme funded jointly by the Department for International Development (DFID), reference STEG_LOA_PP10_Alessandria_Johnson_Yi. The views expressed are not necessarily those of DFID. The views expressed herein are those of the authors and do not necessarily reflect the views of the National Bureau of Economic Research, Federal Reserve Bank of Dallas, and the Federal Reserve System

NBER working papers are circulated for discussion and comment purposes. They have not been peer-reviewed or been subject to the review by the NBER Board of Directors that accompanies official NBER publications.

(C) 2021 by George A. Alessandria, Robert C. Johnson, and Kei-Mu Yi. All rights reserved. Short sections of text, not to exceed two paragraphs, may be quoted without explicit permission provided that full credit, including ( $)$ notice, is given to the source. 
Perspectives on Trade and Structural Transformation

George A. Alessandria, Robert C. Johnson, and Kei-Mu Yi

NBER Working Paper No. 28720

April 2021

JEL No. F1,F43,O11,O4

\begin{abstract}
$\underline{\text { ABSTRACT }}$
This paper surveys macroeconomic and microeconomic perspectives on the role of international trade in structural transformation. We start by describing canonical frameworks that have been used to quantify how trade influences sectoral shares of employment and value added. We then pivot to survey micro-empirical evidence on the impact of changes in trade on the allocation of labor across sectors and productivity at the firm level. In this, we put special emphasis on the role of participation in global value chains and inward foreign direct investment in mediating these effects. Next, we evaluate evidence on the barriers to trade faced by low-income countries, with special attention to recent work that measures these costs taking firm dynamics into account. We conclude by discussing how these micro-perspectives can be integrated into macro-models to advance our understanding of structural change.
\end{abstract}

George A. Alessandria

Department of Economics

University of Rochester

Harkness 204

Rochester, NY 14627

and NBER

george.alessandria@ rochester.edu

Robert C. Johnson

University of Notre Dame

Department of Economics

3060 Jenkins Nanovic Hall

Notre Dame, IN 46556

and NBER

rjohns24@nd.edu
Kei-Mu Yi

Department of Economics

University of Houston

3623 Cullen Blvd.

Houston, TX 77204

and Federal Reserve Bank of Dallas

and also NBER

yik.work@gmail.com 


\section{Introduction}

This paper explores the role of international trade in structural transformation, broadly defined as the evolution of sectoral shares of employment or value added as countries develop over time.

We begin by reviewing canonical frameworks linking trade and structural transformation in Section 1. In standard models, international trade influences sectoral shares through two channels. First, trade allows for specialization, which affects the sectoral composition of economic activity. Second, the ability to trade shapes how other forces (e.g., changes in productivity) translate into patterns of industrial specialization. Recent research has used quantitative models to study the role of these channels for advanced and middle-income countries, with emphasis on understanding the evolution of manufacturing employment. An important direction for research is to evaluate how these frameworks can be adapted to understand structural change in low-income countries, which requires the elaboration of various microeconomic mechanisms that are relevant in the low-income context.

To that end, we survey empirical evidence on how changes in trade contribute to structural change in Section 2. We first discuss reduced form empirical evidence that sheds light on the impact of changes in trade on the allocation of workers across sectors, and between informal and formal firms within manufacturing. We then explore recent work that examines the link between participation in trade and productivity at the firm level. We highlight the role that participation in global value chains may play in facilitating industrialization, particularly through the impact of imported inputs on productivity and the role of spillovers from foreign investment onto domestic firms.

In Section 3, we turn our attention to trade costs as an explanation for why many lowincome countries are not as involved in trade as one would expect given their economic fundamentals. We discuss direct and model-based evidence suggesting that aggregate trade costs are higher in low-income countries. Further, we emphasize specific issues related to measuring these costs in the presence of trade dynamics, as induced by transitions to changes in trade policy or aggregate fluctuations. We also discuss how current research is using firmlevel data to identify the precise nature of policy and non-policy barriers to trade. This research points to the importance of durable investments, with uncertain returns, that firms must undertake to enter into international trade. We describe how transaction level data can be used to identify barriers to trade and study how firms manage their supply chains.

We bring these strands of work together in Section 4, where we highlight ways in which canonical macro-structural change frameworks could be developed further to incorporate insights from micro-oriented empirical research. There remain many unanswered macro-level 
questions about how important these micro-mechanisms are for understanding structural change. We conclude in Section 5 with speculative comments on how the COVID-19 pandemic may influence the role that trade plays in structural transformation in the future.

\section{Theoretical Frameworks for Structural Change in the Open Economy}

International trade can shape structural transformation via two main channels. First, lower trade barriers facilitate specialization, which then affects the sectoral composition of employment or value-added. Second, under a given set of trade barriers, policy changes or other shocks to the economy affect specialization patterns, which will also affect the sectoral composition of employment or value-added. Due to the globalization of the world economy over the past half-century, both of these channels have become increasingly important.

Lower trade barriers can play a key role in structural change. The sources of lower trade barriers can be technological, such as the lower international shipping costs that followed from the development and subsequent widespread adoption of containerization. Alternatively, the lower trade barriers can originate from policy, such as lower tariff rates and diminished use of quotas. These lower barriers facilitate specialization through several forces, the most prominent of which are comparative advantage and economies of scale. Comparative advantage operates through both the demand-side (importing country) and the supply-side (exporting country) to increase specialization. Thus, a simple, yet important, implication of specialization is that production is no longer tightly linked to domestic demand. Foreign demand matters too. To the extent that specialization occurs at the sector level, it will shift the sectoral composition of employment and value added. For example, the Kennedy, Tokyo, and Uruguay rounds of GATT negotiations, the forerunner of today's WTO, successively reduced tariff rates on most goods, thus allowing many countries to specialize in manufacturing. This specialization, in turn, led to increase employment and value-added shares for the manufacturing sector.

In addition, for a given set of trade barriers, policy changes or economic shocks can affect variables such as tax rates, productivity, and the input-output structure of the economy. Changes in these variables can then re-shape specialization patterns with corresponding consequences for the sectoral composition of employment and value added. For example, an increase in a country's manufacturing productivity will, all else equal, shift the country's comparative advantage towards the manufacturing sector. The country will either import less or export more in manufacturing, and resources will shift to that sector. 
Hence, lower trade barriers, as well as shocks to policy and other variables under a given trade regime, are two channels by which international trade can have an integral role in structural change. These channels draw from well-known concepts and frameworks. Until recently, however, research on the role of international trade in structural change has been minimal, if not non-existent. Virtually all of the empirical and quantitative research on structural change employed frameworks built around two other forces - non-homothetic preferences and asymmetric sectoral productivity growth. Non-homothetic preferences are a demand-side mechanism that captures the fact that as countries become richer, households shift their consumption basket away from agricultural products towards manufactured goods and services. Recent empirical research has shown that these non-homotheticities persist even in wealthy nations. Asymmetric sectoral productivity growth (or the "Baumol" effect) is a supply-side mechanism that generates changing relative prices over time, which, in conjunction with non-unitary substitution elasticities, implies expenditure shares on agriculture, manufacturing, and services change over time.

Following Matsuyama (2009), model-oriented research on the role of international trade in structural change has emerged. Virtually all of this research follows the approach of developing theoretical models, then calibrating them, and finally simulating or conducting counterfactual exercises to assess the role of international trade in structural change. This research has yielded some important results on the importance of international trade overall. For example, Uy, Yi and Zhang (2013), Betts, Giri and Verma (2017), and Teignier (2018) study features of South Korea's trade reforms beginning in the 1960s, and they all find that these reforms had quantitatively important effects on Korea's structural change, especially the movement from agriculture to manufacturing. Cravino and Sotelo (2019) develops a model of trade-induced structural change to explain the increase in the U.S. skill-premium. Swiecki (2017) and Sposi (2019) conduct broader analyses across many countries on the importance of key mechanisms in structural change. Swiecki (2017) finds that sector-biased technical change is the most important mechanism, with non-homothetic preferences and international trade playing important roles in particular subsets of countries. Sposi (2019) finds that differences in input-output tables across countries can account for about threefourths of the hump-shaped pattern in the industry value-added share as per capita income evolves.

This research has only scratched the surface of what could be done to better understand the channels and mechanisms by which international trade can affect structural change. There are two broad avenues for future research that applies theoretical frameworks. The first is to expand the set of "case studies." As noted above, much of the existing research focuses on growth miracle countries like South Korea or advanced economies like the United 
States. However, countries in which the comparative advantage is in agriculture or mining should be studied too - these would be cases in which international trade would work against the typical structural change path. In addition, none of the above studies examines countries in Africa, nor do they examine the lowest income countries. Thus, we believe studying structural change in low-income countries through the lens of quantitative structural models is an opportunity for future research.

The second broad avenue for future research is to enhance the canonical theoretical frameworks, drawing on insights from modern research on international trade and firm dynamics. We discuss this approach in Section 4 below. To set the stage for this discussion, let us now turn to the empirical research relevant to tracing out the mechanisms by which trade can influence structural change.

\section{Empirical Evidence on Mechanisms}

In theories of structural change, changes in demand-side "pull factors" (e.g., shocks to demand) and supply-side "push factors" (e.g., changes in productivity) determine the allocation of factors across activities. In this section, we discuss two branches of empirical literature that explores the role of trade via these two mechanisms. The first examines how trade shocks - either changes in import penetration or export market access - lead to reallocation of factors. ${ }^{1}$ The second studies the role of trade and multinational activity in shaping productivity.

\subsection{Trade Shocks and Factor Allocation}

An important literature uses quasi-experimental empirical techniques to study adjustment to changes in trade. Within this literature, one stream of work focuses on responses to changes (typically increases) in import penetration. Because imports are endogenous with respect to the level of domestic demand for them, empirical work focuses on studying the cross-industry or cross-region impacts of quasi-exogenous import liberalization or exogenous surges in imports driven by foreign supply/demand factors. A second stream of research redirects attention to changes in export market access - e.g., due to foreign liberalization or other external demand shocks.

From a structural change perspective, the most natural question to ask would be: how

\footnotetext{
${ }^{1}$ To clarify the scope of our discussion, we focus on the allocation of factors across sectors. Thus, we do not engage research on the allocation of factors across firms within a sector, which plays an important role in models of trade with heterogeneous firms. To the extent that this within sector reallocation alters sectoral productivity, it may be an additional mechanism through which trade influences structural change.
} 
do these import penetration or export market shocks alter the allocation of factors across sectors? Increased imports provide competition for domestic producers that produce similar goods, but benefit firms that use imports as inputs in their production process (we discuss benefits of imported inputs further below). The net impact of these changes on the allocation of factors across industries depends on the sectoral composition of the import surge, and may be difficult to discern ex ante. On the export side, increases in export demand naturally pull factors into production of exportable goods and/or firms that participate in exporting. This reallocation is likely to raise aggregate productivity, as various theories suggest exporting industries or firms are more productive than those not engaged in trade.

While this focus on sectoral reallocation in response to shocks speaks to theories of structural change, it has not been the main focus of the modern empirical literature. Rather, most work has focused on how differential exposure to trade shocks leads to differential outcomes in local (i.e., regional) labor markets, including employment, educational outcomes, poverty counts, etc. This strategy is a powerful technique for studying the mechanisms through which trade affects the economy, though it is less well suited to addressing macroeconomic (i.e., general equilibrium) questions. In advanced countries, this line of work is typified by Autor, Dorn and Hanson (2013), while Topalova (2010), McCaig (2011), Dix-Carneiro and Kovak (2017), and Erten, Leight and Tregenna (2019) are a excellent examples of this approach in middle income contexts (India, Vietnam, Brazil, and South Africa, respectively).

One fruitful area for work is in re-applying the basic identification strategies employed by these papers to study questions that are explicitly about structural change. In this vein, we highlight three recent examples of frontier work. The first is research by Erten and Leight (forthcoming) on how the surge in exports following China's entry into the WTO led to localized structural change in China. Following the normalization of trade relations with the US, some regions experienced larger declines in (export) tariff uncertainty due to their pre-existing composition of output, and this reduction of uncertainty was followed by a surge of exports at the region level, particularly exports of manufactured goods. This shock raised GDP at the region level, and it appears to have led to workers to shift out of agriculture into manufacturing. Note that these results suggest that structural change occurred within regions as a result of the export surge; further work is needed that focuses on how these effects may be aggregated into economy-wide structural change, where workers may be reallocated within and across regions in response to trade shocks.

In a related vein, McCaig and McMillan (2020) examines factor reallocation in response to a quasi-exogenous import liberalization shock in Botswana, following decreases in tariffs of the Southern Africa Customs Union (of which Botswana is a member) that were lowered as part of South Africa's liberalization in the mid-1990's. These tariff changes both 
generated more import competition in Botswana, and dampened South African demand for exports from Botswana due to South Africa's external liberalization. McCaig and McMillan document that the liberalization did not lead to reallocation of workers across industries in Botswana, in contrast to the evidence from China above. They argue this lack of structural change is consistent with prior work that found limited factor reallocation across sectors in response to trade liberalizations.

Even if trade shocks do not move factors across industries, they may still lead to withinindustry reallocation that raises productivity. McCaig and Pavcnik (2018) studies reallocation of workers between informal household firms and formal firms within the manufacturing sector, a margin that is likely particularly important in low-income contexts where informality is pervasive. McCaig and Pavcnik focus on Vietnam, which experienced an export boom following the 2001 United States-Vietnam Bilateral Trade Agreement, which had differential impacts across industries. Industries that saw larger declines in US tariffs and faster export growth experienced large declines in the share of workers in household firms, particularly in manufacturing. These changes account for a large share of economy-wide declines in informality during this period. The reallocation of labor toward formal firms also appears to raise productivity, as McCaig and Pavcnik document that there is a sizable labor productivity gap between informal and formal firms.

Set against these results, Menezes-Filho and Muendler (2011) uses matched employeremployee data to track workers over time following trade liberalization in Brazil. They observe worker displacements at firms that experience more intense import competition, which is unsurprising. Importantly, these displaced workers are only slowly reabsorbed by exporting firms and comparative-advantage industries, and workers transition on net to non-traded industries, unemployment, and informal employment over time. To the extent that the unilateral liberalization raised import competition, without providing new export opportunities, this is not necessarily inconsistent with the McCaig and Pavcnik (2018) evidence. Together with McCaig and McMillan (2020), it raises concerns about whether factor reallocation raises productivity in realistic liberalization episodes. ${ }^{2}$

All together, these papers point to credible empirical designs to identify the mechanics through which trade leads to structural change. Nonetheless, work in this area is relatively scarce, and there will be large gains to providing and dissecting similar evidence for other low-income contexts. For example, it would be useful to know whether the Erten and Leight results regarding moving out of agriculture in China hold in other contexts, where barriers to

\footnotetext{
${ }^{2} \mathrm{~A}$ separate set of questions are related to the welfare effects of worker displacements due to trade. One might be concerned that displacements are particularly costly when workers do not have access to social insurance programs, as in most low-income countries. We are not aware of work that addresses these concerns explicitly, though they would be important for understanding the political economy of trade reforms.
} 
moving off the land may be more substantial (e.g., where agricultural and non-agricultural activities are spatially separated, or where lack of property rights constrain individual's ability to leave the land). Or, it would be useful to further study the role of trade shocks in reallocating workers from informal to formal firms, in contexts where barriers to factor mobility may be higher than in Vietnam. Lastly, like in the local labor market literature, it will be further useful to examine how results obtained from differences-in-differences type designs aggregate up to shed light on aggregate patterns of structural change.

\subsection{Trade, GVCs, and Productivity}

There is a large body of work that studies the causal impact of engagement in international trade on firm performance. ${ }^{3}$ On the export side, there are many studies that point to gains in firm performance due participation in export markets. On the flip side, there is also significant evidence that foreign imports contribute to productivity growth as well. In both these areas, one can appeal to arguments that either backward participation (importing) or forward participation (exporting) in value chains that span borders facilitates cross-country technology and knowledge transfer, though smoking gun evidence on these channels is incomplete. In a related vein, there is also a body of work that examines how foreign firms operating locally (via foreign direct investment) may serve as a conduit for productivity spillovers to domestic firms.

In this section, we briefly review these three related areas of work. Most of the existing evidence on these channels comes from middle or high income countries, so we highlight open questions about the role for these channels in low-income countries. Further, most of the evidence is micro-economic in nature. We conclude the section with thoughts about the potential for research that seeks to answer questions about the importance of these channels for macroeconomic structural change.

\subsubsection{Imported Inputs}

The ability to import intermediate inputs to produce confers a host of benefits on participating firms. At a basic level, the replacement of a high cost domestic source for a cheaper foreign source of inputs allows firms to produce with lower marginal costs. More generally, importing may allow firms to access a larger variety of inputs, or higher quality inputs from high income countries, both of which reduce effective production costs as well. These unit cost reductions lead firms to expand and appear more productive. In some cases, this will

\footnotetext{
${ }^{3}$ Our emphasis here is tailored to highlight particular issues pertaining to participation in global value chains and trade in low-income countries. See De Loecker and Goldberg (2014) for a more comprehensive review of the literature on the impact of trade on firm performance.
} 
make activities that that are unprofitable in autarky profitable in the open economy. In the extreme, production may not even be feasible (at any price) without foreign inputs, if no suitable domestic input source or substitute input exists. This has knock on effects for firm demands for (and use of) labor and capital. Further, cost reductions that allow firms to expand their scale make fixed cost investments more attractive. Thus improving access to imports may trigger complementary investments in entering export markets, expanding product scope, raising output quality, or adopting new technologies.

Reflecting these forces, there is a large literature on the impacts of replacing domestic sources of inputs and business tasks with foreign (offshore) sources. While much of this work focuses on high income countries, there is both work that features emerging markets and low-income country contexts. A collection of papers uses episodes of import liberalization in Indonesia and India to study how changes in import tariffs influence firm performance. In Indonesia, Amiti and Konings (2007) finds that firms that import inputs that experienced large tariff cuts experienced improvements in their productivity. Topalova and Khandelwal (2011) provides a similar results for India. In both cases, the authors examine output and input tariffs simultaneously, and find larger productivity effects for input tariff liberalization than output tariff changes that alter the firm's competitive environment. While Amiti and Konings explore various mechanisms to explain the results - product switching, changes in markups, etc. - they do not have the data necessary to completely pin down the sources of this productivity growth.

Two papers on India go further to examine the nature of firm adjustments to import liberalization. Goldberg et al. (2010) links tariff liberalization to increased variety of inputs imported by the firm, and in turn to expansions in the scope of output products produced. This is a prime example of complementary investments, where importing triggers investment (incurring fixed costs) needed to produce new products. The authors argue that these improvements in scope are not simply due to reductions in the effective price of inputs, but rather that import variety per se is important for relaxing technological constraints on production of new goods. ${ }^{4}$ Looking at price setting rather than product scope, De Loecker et al. (2016) show that firms do not fully pass-through cost reductions attributable to import tariff cuts - i.e., markups rise. This incomplete pass-through raises questions about whether improvements in firm-level productivity observed in various contexts translate into gains for downstream buyers (whether consumers or downstream firms in the domestic value chain). This is an important open question.

\footnotetext{
${ }^{4}$ In addition to expanding import variety, imports (particularly form high income countries) are likely to be higher quality than domestic alternatives. Halpern, Koren and Szeidl (2015) links import variety and quality to firm productivity in Hungary.
} 
Beyond India and Indonesia, it would be helpful to understand how these types of mechanisms translate to two distinct settings. ${ }^{5}$ First, we are not aware of studies that examine the role of imported inputs on firm productivity in low-income country settings. This is likely due to the lack of data sets that link firm-level variables (production, employment, materials use, and so on) to firm-level import transactions for those countries. However, new opportunities are likely to emerge over time for this sort of research. For example, Spray (2020) uses a novel firm-to-firm transactions data set matched with customs data and balance sheet information for Uganda. While these data sets cover only formal firms, more effort to locate and develop these sources would be useful.

Second, in the middle income context, imported inputs are often used by processing firms to produce exports, as in Mexico or China. In the low-income context, Bangladesh is a country that has used two-way processing trade in the apparel industry to facilitate industrialization. Whether explicit attachment to GVCs via processing trade is a desirable policy outcome is an open question. One issue is that the processing trade is often conducted under special legal regimes that allow for tariff rebates, and processing firms often benefit from (non-tariff) tax incentives, input subsidies, or other policies as well. Whether these programs are cost effective at stimulating industrialization is unknown. ${ }^{6}$ In a different vein, there are important questions about whether encouraging processing trade has dynamic benefits. Do firms/industries that start as processing enterprises exhibit rapid growth and the ability the transition to more sophisticated activities over time? Do workers who start in the processing sector carry knowledge with them as they transition to non-processing jobs? Do owners of firms spin-off dynamic firms over time? Do new do processing exports stimulate development of upstream industries that supply inputs to exporters? We know little about these questions, which all speak to whether spending resources on encouraging processing exports is good policy.

\footnotetext{
${ }^{5}$ Looking forward to discussion below regarding inventories and trade costs, we also raise a point about measuring productivity gains here. Khan and Khederlarian (2020) argues that omission of inventory holding costs in computing revenue based productivity leads to overestimation of the productivity gains of import liberalization. This is related to a broader issue in this literature: productivity changes hinge on accurate measurement of firm-level input price indexes (equivalently, input quantity). Input price and quantity measurement is challenging in most micro-data sets, and it is particularly difficult when the mix of inputs used in production changes rapidly due to liberalization itself. As such, many studies include changes in input prices in the firm's measured productivity residual.

${ }^{6}$ Dai, Maitra and Yu (2016) show that Chinese firms in the processing trade sector are less productive than ordinary exporters. Whether this pattern holds elsewhere is unknown; if it does, it suggests that countries are effectively subsidizing unproductive firms via their processing trade regimes.
} 


\subsubsection{Exporting and Productivity}

Changing focus from imports to exports, there is a companion literature on how exporting influences productivity at the firm at the firm level. Here the emphasis is on how exporting may stimulate complementary investments that raise firm productivity, or how connections with foreign buyers serve as conduits for knowledge/technology transmission.

One benefit of access to foreign markets is that it delinks firm size from the size of the local market. That is, the size of an exporting firm is determined by the combined size of the home and foreign markets, which is typically substantially larger than the home market alone. This is likely to be particularly important in low-income countries, where local demand for manufactures is relatively small. Exporting expands the size of the market for manufactures, which may lead firms to engage in complementary investments.

Market scale may matter for firm performance for several reasons. Most obviously, internal returns to scale at the firm level may allow firm productivity to increase due to export market entry. Further, increases in firm scale also make complementary investments that are subject to fixed costs more attractive to the firm, thus enhancing firm capabilities. For example, Bustos (2011) documents that improved access to foreign markets led Argentine exporting firms to invest in technology upgrading, including spending on computers and software, payments for technology transfers, and spending on innovation activities within the firm (such as R\&D). Other papers have emphasized quality upgrading, particularly for LDCs where firms sell to higher income foreign consumers [Verhoogen (2008); Hallak and Sivadasan (2013)]. Importing inputs is also a complementary activity, due to fixed costs of participation in import markets [Bernard et al. (2018)]; Expansion into export markets may thus lead to productivity improvements through the mechanisms discussed in Section 3.2.1.

The existing evidence of the role of complementary investments has been developed primarily in middle and high income contexts. One important question about applicability of these results to lower income contexts concerns how constraints may impinge on the ability of firms to take advantage of market scale. Where there are frictions that impede optimal investment at the firm level, then exporting need not trigger complementary investments. Identifying the constraints that LDC exports face in leveraging exporting for productivity improvement is an important area for work.

A second distinct benefit of exporting is that it may open up opportunities for exporting firms to learn from their buyers. This type of knowledge or technology diffusion may be particularly important for firms from developing countries who are engaged with sophisticated buyers (e.g., multinational firms) in advanced countries. While there is a venerable

literature on learning-by-exporting, there are persistent concerns about whether productivity improvements after entry into export markets reflect true learning, or other changes (e.g., to 
markups, product quality, or the firm's project mix) that are difficult to control for properly. Atkin, Khandelwal and Osman (2017) turns to a randomized controlled trial to sort these channels out. They find evidence that Egyptian carpet producers that randomly receive export orders experience improved firm performance, including higher profitability. Further, they present a suite of evidence that suggests that learning-by-exporting plays an important role in explaining this improved performance.

Despite recent advances in identification of learning-by-exporting effects (experimental or otherwise), one overlooked area for empirical work is whether engagement with foreign firms as part of the global value chain (as input suppliers, in particular) facilitates learning by exporting. It is commonly asserted that downstream buyers have strong incentives to invest in the productivity of their upstream input suppliers, since downstream firms benefit from higher productivity upstream. Further, long term relationships between firms matched via the GVC may allow for greater transfers. How important these features of GVCs are in practice is largely unknown.

\subsubsection{FDI and Productivity Spillovers}

Distinct from direct participation in trade, local firms may also participate in the global value chain by engagement with multinational firms, who establish a local presence either to serve the local market or the export market. The arrival of a multinational firm obviously has direct effects - as multinationals bring know-how, technology, and organizational capital, displacing a domestic firm with a multinational firm typically yields direct industry productivity gains. An important literature seeks to identify gains above and beyond these direct effects, focusing on productivity spillovers of foreign multinationals onto domestic firms.

The foundation of this literature are industry-level results that analyze domestic firm

or industry outcomes associated with changes in foreign firm presence. Within a large literature, Javorcik (2004) stands out. Looking beyond the impact of multinationals on their direct domestic competitions (in the same industry they enter), Javorcik finds positive productivity spillovers of multinational entry for firms in upstream industries, and negligible effects downstream in Lithuania. Lu, Tao and Zhu (2017) provides recent confirmation of these results for China, with identification based on differential FDI liberalization across sectors following China's WTO accession.

In the low-income context, Crescenzi and Limodio (2020) examines the impact of Chinese FDI in Ethiopia. An interesting element of this work is that it adopts a local labor markets style approach to identification. The first piece of the strategy is a set of quasi-exogenous changes in the sector composition of Chinese FDI inflows into Ethiopia, driven by changes in Chinese export taxes that changed the optimal mode (export vs. FDI) of serving the 
Ethiopian market. The second element is that Chinese FDI in a given industry was predominantly allocated to geographical areas in Ethiopia that already specialized in that industry. Crescenzi and Limodio use this natural experiment to examine spillovers from Chinese FDI, finding that firms in the same location and industry as Chinese FDI inflows contract their operations (reducing production, employment, investment, and input use), while firms both upstream and downstream expand. Broadening out, the authors also track local economic development over time, using data on night lights. They find no impact on regional economic activity at the time of FDI inflows, consistent with offsetting positive and negative effects, but they also find positive medium term increases (over 6-12 years) in light output.

One shortcoming of this existing work is that it infers upstream and downstream exposure to multinationals based on industry-level input-output linkages, rather than observing actual connections of firms to multinational partners in the production chain. Alfaro-Ureña, Manelici and Vasquez (2020) makes progress in addressing this shortcoming using a unique firm-to-firm transactions data set for Costa Rica that identifies the precise timing an individual firm becomes a supplier to a multinational firm. This allows Alfaro-Urena et al. to implement an event study type analysis, which reveals that firms experience improvements in productivity upon initiating new supply relationships with multinational buyers. Correspondingly, they expand in size (employment), and they expand sales to non-multinational domestic buyers. This expansion of sales to other domestic firms seems to be driven by reputation (perceived firm quality), rather than productivity effects. It also suggests that even firms that don't directly serve the multinational benefit from FDI.

Staying with this theme, there is another mechanism via which benefits of multinational entry may accrue to domestic firms that do not directly interact with the foreign firm. Rodriguez-Clare (1996) suggests that when a foreign firm enters, it generates new demand for inputs, which expands the variety of input supply. This increased supply of local input varieties then benefits other domestic firms. Kee (2015) looks for evidence on this mechanism in the Bangladesh garment sector. She finds that expansions of foreign firms in Bangladesh (driven by EU trade policy) lead to better performance at domestic firms that share suppliers with those foreign firms. Further, she provides additional evidence that changes in variety driven by FDI explain productivity changes at domestic firms. In sum, the domestic production network is a conduit for indirect spillovers from direct spillovers from multinationals. One nice feature of this work is that Kee implements a specially designed survey to collect firm-level data, identifying proxies for variety and eliciting information from firms about the identities of their top input suppliers. This is a useful template for overcoming data constraints elsewhere, where firm census or firm-to-firm transactions data sets are 
unavailable. $^{7}$

While the collected body of evidence suggests that multinationals have positive productivity spillovers on domestic firms, two major caveats are worth noting. First, if foreign firms use advanced technologies in production, only a subset set of domestic firms who can adopt complementary technologies and/or produce compatible inputs may benefit from foreign firm entry. More generally, technological or knowledge spillovers require absorptive capacity to benefit from them. Identifying whether spillovers are operative, or what the barriers to them might be, in a low-income country context seems a useful area for more work. Second, in many LDCs the sector composition of FDI is likely different than in the middle income countries that feature prominently in the literature (e.g., Lithuania or China). For example, in Africa much FDI is directed toward the natural resources sectors. African countries have also seen an influx of FDI into the food sector [World Bank (2020)]. Whether any of these channels are operative in these contexts is worth investigation.

\section{Impediments to Trade in Developing Countries}

It is still unclear why low-income countries are so much less involved in the global trading system than middle-income or advanced economies. Their persistently low levels of trade integration are generally attributed to a host of factors, including trade policy, geography, tastes and technology (or other aspects related to the stage of development), politics and institutions. And many of these factors interact with each other. In this section, we review evidence on the sources of low trade participation by developing countries, starting from a macro perspective and then moving toward more micro-based evidence.

\subsection{Trade Barriers for Low-Income Countries}

Direct and model-based measures of trade barriers suggest that both policy and non-policy barriers to trade are relatively high in low-income countries. Direct measures of trade policy barriers, including tariffs and non-tariff barriers, confirm that import and export barriers fall with the stage of economic development, although the decline in tariff barriers with development is offset in part by a rise in non-tariff barriers [Kee, Nicita and Olarreaga (2009), Hoekman and Nicita (2011)]. ${ }^{8}$ On the import side, a key question is whether the relatively

\footnotetext{
${ }^{7}$ In the specific Bangladeshi context, there is potential for rich data sources could be used in research. For example, Grossi, Macciavello and Noguera (2020) exploits a rich data set on transactions between domestic garments firms and foreign buyers, together with information about input sourcing by domestic firms.

${ }^{8}$ Low-income economies have relatively high domestic trade costs and import barriers. See high-quality surveys such as the World Bank's Doing Business Survey or Logistic Performance Index, for example.
} 
high policy barriers in developing countries reflect fiscal, external, or domestic political economy considerations. Revisiting the long-standing issue of the determination of product-level tariffs, as in Broda, Limao and Weinstein (2008), but interacted with development offers an interesting avenue for research.

On the export side, high export barriers faced by low-income countries arise from a range of policy and non-policy factors. Some can be attributed to geography: natural trading partners of low-income countries tend to be other low-income countries, with relatively high inward barriers themselves. Further, low-income countries tend to be more specialized in high-tariff agricultural goods [Fajgelbaum, Grossman and Helpman (2011), Fieler (2011)]. Moreover, the increase in preferential trade agreements among advanced economies has made breaking into some of the most profitable markets even more challenging.

The gravity model provides a parsimonious way to identify bilateral trade barriers from bilateral trade flows. Gravity-based estimates by Waugh (2010) suggest that exporting costs are particularly high in low-income countries. While the gravity model is instructive, it also has several shortcomings. First, it is based on a static theory that does not fit the evidence on the effects of trade policy on trade or the movements in trade over the business cycle or at the firm level. ${ }^{9}$ Second, the model provides very little evidence on the precise barriers that domestic and foreign firms face in domestic and international markets.

A key challenge is then to identify whether the relatively low observed trade flows in low-income countries reflect current or future high trade costs, or the transition from past policy choices or fluctuations in economic activity. It is also unclear whether the transition process depends on the stage of development, through macroeconomic factors such as financial openness [Alessandria, Choi and Lu (2017), Reyes-Heroloes (2016)]. These dynamic effects also make it challenging to quantify the role of trade policy on economic activity, since it is not clear whether the benefits will come early or late in a reform. ${ }^{10}$

Beyond affecting the relationship between trade and trade policy, the dynamics of adjustment are also important for understanding the benefits of trade, measured by increased income per capita or growth. The early empirical work following the wave of trade liberaliations in the 1980s and 1990s found modest or non-existent gains from trade reforms [Rodriguez and Rodrik (2001)]. With more distance from these reforms, there is growing evidence of more significant gains [Irwin (2019)]. Building on these reduced-form empirical

\footnotetext{
${ }^{9}$ For instance, Baier and Bergstrand (2007) and Baier, Bergstrand and Feng (2014) show that preferential free trade agreements only gradually increase bilateral trade flows. Jung (2012) estimates that less than half of the trade expansions from a free trade agreement occurs within the first ten years. Likewise, the sharp movements in trade over the cycle do not reflect large changes in policy or trade barriers, but rather dynamic aspects of trade that are outside the static gravity model.

${ }^{10}$ Mix (2020) develops a multi-country model with transition dynamics to study how the dynamics effects of trade reforms are shaped by financial openness, geography, country size, and development.
} 
findings, it would be useful to revisit these findings in structural models with explicit dynamics. In particular, Alessandria, Choi and Ruhl (forthcoming) argue that the rich dynamic implications of changes in trade policy are poorly approximated by static models, both along the transition path and in the long-run.

\subsection{Microeconomic Determinants of Trade}

While much can be learned about the determinants of trade from aggregate, bilateral, and industry trade flows, the increased availability of firm- and customs-level data has shifted research toward identifying the technology and policy barriers to firm-level involvement in international trade. The focus here has shifted to understanding how these frictions influence firm's export, import, entry, and technology adoption decisions.

Often the researcher must choose between data sources. One common data source is industrial census data, which typically contains firm-level panel data with rich firm characteristics (capital intensity, labor, input usage, inventories, domestic and imported input use, domestic and foreign sales, assets). An alternative source is derived from customs data, which often records transaction-level data that has rich information on input sources, export destinations by product, transaction or relationship (customer/supplier), but little information on domestic activities of the trading firm. In the best case, these sources can be merged. Most existing studies focus on a single country, with freely available data from Colombia and Chile making them the most studied countries, but results tend to be comparable across a wide range of countries. A good source of data from developing countries is the World Bank's Exporter Dynamics dataset (Fernandes, et al. 2016) and the Enterprise Survey.

The firm-level data can be useful for understanding the barriers to international trade from and to developing countries. Importantly, the panel dimension of the customs data sheds light on the expansion and survival path of firms at relatively high frequency, which is often difficult to study using domestic data alone. The rich heterogeneity in customs data is also particularly valuable to separate the margins that account for low involvement in trade for the country and individual firms. Most work has focused on a participation decision (extensive margin) and the volume of trade per participant (intensive margin). More recent work has shown these decisions can be closely related when looking at high frequency trade shipments.

In moving to more micro-oriented analysis, several key issues must be addressed. First, its important to consider aggregation, as most transactions or firms account for small shares of trade, and the behavior of small and larger firms in trade can be quite different. The issue of aggregation is particularly important in developing countries, where there are many 
small firms that are rarely involved in trade, as well as informal firms that are not captured in the data. Second, one must be sensitive to the unit of time when analyzing micro data: trade flows can be quite infrequent, particularly so for developing countries. Third, it is important to combine the data with models to identify the level of frictions, rather than just the heterogeneous effects of trade barriers across firms. General equilibrium models are particularly valuable here as they allow us to use micro and macro data to infer behavior of informal or non-surveyed firms. We now discuss two ways in which the micro data is proving useful to identify particular forms of firm frictions and trade barriers that may interact with development.

\subsubsection{Investing in Market Access}

By now, the salient features on firm involvement in trade are well-known: exporters and importers are rare, relatively productive, and quite persistent. ${ }^{11}$ These features are generally explained by heterogeneity in both the costs and benefits of trade. While much of the quantitative trade literature has emphasized cross-sectional differences in firm internationalization, it is the panel dimension on trade that has yielded the greatest insights on the precise nature of the costs and benefits of trade.

Starting with the structural analyses by Roberts and Tybout (1997) and Das, Roberts and Tybout (2007), attention has focused on sunk investments that firms must undertake to participate in trade. ${ }^{12}$ Early work emphasized large upfront sunk costs, but later work shows that it takes repeated investments in market access for new exporters or importers to be involved in trade with significant volumes [Ruhl and Willis (2017)]. Many firms have short-lived export or import spells, while successful traders take time to trade with significant volumes. The precise source of the uncertainty from this investment is unclear. Do these reflect information differences? Matching frictions? Or uncertainty in delivery costs? Are they technological or policy based? Identifying the precise friction will help to come up with more targeted industrial policy or eliminate distortions.

The dynamics of trade participation are consistent with firms making repeated, risky investments to accumulate a form of organizational capital that yields an uncertain stream of profits. This investment depreciates relatively quickly once a firm exits an export market. Understanding how this firm-level organizational capital can be used across products and destinations is an unsettled issue [Albornoz et al. (2012), Morales, Sheu and Zahler (2019)]. Moreover, understanding whether there are spillovers to non-trading firms from these firmspecific investments in terms of information about import or export opportunities or reduced

\footnotetext{
${ }^{11}$ See the recent survey by Alessandria, Arkolakis and Ruhl (2021).

${ }^{12}$ These types of models are also needed to make sense of the aggregate trade data we discussed earlier.
} 
costs of market access remains an open question.

Several recent papers have used customs data to document substantial differences in export entry, growth, and survival rates that differ by country characteristics [Mix (2020), Albornoz, Fanelli and Hallak (2016), Steinberg (2020)]. It would be useful to broaden the focus of this agenda by estimating the source and destination specific export costs and uncertainty consistent with the observed patterns of firm-level trade. Mix (2020) shows that matching firm-level churning behavior is important for understanding the short-run and long-run effects of trade agreements. Moreover, Alessandria and Avila (2020b) use firm-level data to estimate how these barriers change over time and interact with tariff liberalization.

Consistent with the view that firms make market penetration investments with uncertain future returns, their investment decisions will depend on a country's level of financial development, as in potential restrictions on borrowing or factors that influence the volatility of expected returns. Leibovici (2018) suggests that financial frictions shape sectoral comparative advantage, but may have limited effects on overall trade. Further, Kohn, Leibovici and Szkup (2016) and Brooks and Dovis (2019) show that the precise nature of financial frictions will shape the long-run benefits of trade liberalization. Alessandria, Pratap and Yue (2013) shows that the export expansion path following a real exchange rate depreciation will be slower and smaller when the depreciation is accompanied by a rise in borrowing costs. Volatility also seems to lower trade. Merga (2019) shows that greater exchange rate volatility decreases trade and is well explained by a model with sunk-export costs, shipping delays and financial constraints. Additionally, there is strong evidence that trade policy is riskier and more strongly countercyclical in less developed economies [Bown and Crowley (2014)].

\subsubsection{Shipments, Inventories, and Trade}

The availability of high-frequency transaction-level data has yielded rich insights into the nature of domestic and international trade frictions, as well as the operation of domestic and international supply chains. Specifically, starting with Alessandria, Kaboski and Midrigan (2010), it is well understood that the lumpiness in firm-to-firm transactions in trade can be best understood through the lens of a model with fixed transactions costs and inventory holding costs. Firms order infrequently to economize on fixed transaction costs at the cost of higher inventory holding costs. These inventories also serve as a buffer against supply and

demand shocks. Differences in order frequency and size between international and domestic transactions provide information on the size of these order costs as well as the costs of shipping lags. A key feature of firm's importing or exporting participation is a substantial increase in inventory holdings. Nadais (2017) develops a parsimonious way to estimate 
domestic and international fixed transaction costs using inventory and import penetration data. Khan and Khederlarian (2020) shows that the costs of these higher inventory holdings are not captured well in existing estimates of productivity discussed earlier and thus lead researchers to overstate the firm-level productivity gains following a trade reform.

Using customs data, Kropf and Sauré (2014) and Blum et al. (2019) document substantial differences in the size of shipments across destinations. They use these differences to estimate how fixed transactions costs depend on gravity type measures and development. Specifically, Blum et al. (2019) shows that fixed transactions fall strongly with development, which means that they can explain why developing countries appear to face high export barriers to trade in gravity models, as in Waugh (2010). Blum et al. (2019) argues that these high fixed costs in less developed economies induce larger inventory holding and lead firms to specialize in lower quality products which affects a country's total factor productivity. Using the richness of import and export transactions by source and destination, together with theory, will allow researchers to sort out the precise frictions influencing firm behaviour.

\section{Advancing Beyond the Benchmark Trade and Struc- tural Change Framework}

All together, the previous sections speak to the fact that there is a significant body of evidence on the mechanisms through which trade impacts firm performance and influences the allocation of labor across sectors. There is also detailed evidence on the nature of frictions that impede international trade in low-income countries. Though there remains ample scope to develop this microeconomic evidence further, there is also a need to better understand how these mechanisms fit into a broader macroeconomic picture. ${ }^{13}$

The benchmark international trade and structural change framework could be thought of as a model with constant returns to scale production, goods produced in a single stage, trade based on comparative advantage, and with all activity occurring in a static setting (or a sequence of repeated static settings). This has been a powerful and useful framework, as exemplified by most of the research discussed in Section 1 above. However, enhancing that framework with some key developments from research in growth, development, and even other areas of trade may help broaden and deepen our understanding of the channels and mechanisms linking international trade and structural change. The remainder of this section summarizes four directions for research.

\footnotetext{
${ }^{13}$ Though we do not review it here, the empirical macro-literature on trade and economic growth is almost entirely disconnected from this micro-evidence. See Irwin (2019) for a recent survey.
} 


\subsection{Embed Dynamics into Models}

As structural change is a phenomenon occurring over many years, even decades, it makes sense to study international trade and structural change in a dynamic context with long-run growth. Specifically, there are several reasons for developing models with dynamics involving capital and productivity over time. First, as discussed above in Section 2, a great deal of empirical research has linked specific features of international trade and multinational activity to higher productivity. This higher productivity will, in turn, shape capital accumulation over time, and both will affect comparative advantage. So, theoretical frameworks with dynamics can embody feedback effects from trade to productivity and growth, and back to trade. Kehoe, Ruhl and Steinberg (2018) and Lewis et al. (2020) are two recent examples of dynamic trade and structural change frameworks. Second, Alessandria, Choi and Ruhl (forthcoming) argues that the welfare effects calculated from static multi-sector international trade models, i.e., the benchmark international trade and structural change framework, should be viewed with caution, as they ignore the dynamic adjustments over time of entry and exit, which could significantly affect such calculations.

Third, structural change occurs in a setting of long-run growth. Recently, the empirical research has pushed forward on the long-run effects of trade agreements on structural change, as in McCaig, Pavcnik and Wong (2020), which studies this issue for Vietnam. And in the closed economy structural change literature, Herrendorf, Rogerson and Valentinyi (2014) develop the "multi-sector benchmark model" in which endogenous capital accumulation plays a key role. Hence, in order to better interpret the findings of this and similar empirical research from the perspective of how trade interacts with structural change in the long-run, including capital accumulation and technological progress in the models seems essential. A natural reason to embed long-run growth in an open economy structural change model is to allow for Heckscher-Ohlin transmission channels. As capital is accumulated over time, all else equal, a country will shift its specialization to sectors that are capital-intensive. This was traced out in Acemoglu and Guerrieri (2008), but in a closed economy setting. ${ }^{14}$

Embedding these dynamic forces into the models will also facilitate studying two-way feedback from growth to structural transformation and from structural transformation to growth. Regarding the latter feedback, if different sectors require different capital intensities for production, then structural transformation will affect the demand for capital, with consequent implications for aggregate growth.

\footnotetext{
${ }^{14}$ Sposi, Yi and Zhang (2020) provides a model with such feedback effects involving capital accumulation, but it does not have structural change.
} 


\subsection{Unpack the Meaning of Sectors}

While much of the structural change literature focuses on broadly defined sectors, along traditional agriculture, manufacturing, and services lines, there are important differences in economic activities beneath the surface.

For one, we know that the informal sector occupies a large share of employment in most developing and emerging market economies. A key part of structural change is the movement of workers from informal firms to formal firms, which may occur as workers move within and across sectors. In addition, state-owned enterprises coexist with private enterprises in many developing countries. This is another source dimension on which firms differ within and across sectors, and reallocation of economic activity across these segments may play an important role in structural change. Broadly, work aimed at evaluating the role of international trade in reallocating workers across firm types within sectors would have high returns. ${ }^{15}$

Following on this sectoral disaggregation theme, manufacturing and services are broad categories. Manufacturing encompasses everything from automobile tires to high-end memory chips, while services includes both haircuts and investment banking. To have a better understanding of the nature of structural transformation over time, both empirically and theoretically, it makes sense to disaggregate each of these broad sectors into sub-categories, as is done for services in Duarte and Restuccia (2020). This opens up the possibility of addressing how the role of trade in affecting manufacturing or services employment depends on the type of manufacturing or service.

In sum, models of international trade and structural change with a finer definition of sectors can yield insight into how trade affects the informal vs. formal composition of firms, the state vs. private composition, the importance of sub-sectors within manufacturing and services. This insight may be useful for assessing the likelihood that a country's structural transformation will "skip" manufacturing and proceed directly from agriculture to services.

\subsection{Employ Models of Heterogeneous Firms}

Much of the leading research in international trade uses data collected at the firm or establishment level, together with theoretical frameworks with heterogeneous firms. In contrast, canonical models of structural change are built with representative firms within sectors. By extending them to incorporate firm heterogeneity, one can address new empirical and theoretical questions.

\footnotetext{
${ }^{15}$ As discussed above, McCaig and Pavcnik (2018) is one of the few papers that has addressed the role of trade in reallocation across formal and informal firms.
} 
For example, two key features of structural change are the declining part of the manufacturing "hump" and the increasing share of services. Exactly how do these two features interact? Do manufacturing firms exit, and new services firms enter? Do manufacturing firms shift their mix of products over time and eventually become services firms? Or do manufacturing firms continue to exist, but at a smaller level, while services firms expand? What is the role of multinational firms in the above? Most importantly, how do these interactions themselves interact with international trade and/or trade policies?

A few quantitative papers have begun to move in this direction. Alessandria and Choi (2014) studies the interaction between structural change and trade integration in the U.S. through the lens of a multi-sector model of exporter dynamics. Alessandria and Avila (2020a) extends that framework and applies it to study trade integration in Colombia. Both papers bring firm-level data on trade participation to bear on structural change and economic growth. In addition, Ding et al. (2020) empirically studies the transformation of U.S. manufacturing firms to an increasingly services orientation, and then develops a firm-level trade and structural change framework to rationalize these facts. More research along these lines would be useful.

\subsection{Include Global Value Chains}

A key feature of globalization over the past several decades has been the rise of global value chains - goods are made in a sequence of stages with multiple countries contributing along the sequential chain to the final output. Johnson and Noguera (2017) show that domestic value-added embodied in gross exports (ultimately consumed abroad), declined from 82 percent in 1970 to 69 percent in 2007. Put differently, the foreign value-added embodied in a country's gross exports almost doubled during this period. Moreover, they also show that the countries with the greatest GDP growth during this period experienced the greatest increases in foreign content - i.e., the greatest increase in global value chain (GVC) participation. ${ }^{16}$

GVCs facilitate specialization at a finer level than the entire good, and can thus speed up structural change. For example, Mexico's manufacturing sector has grown in part because it has become of the world's leading motor vehicle producers. But, this is due in large part to its participation in the North American value chain, under the umbrella of the U.S. auto companies.

There are only a few models of GVCs, particularly those that emphasize sequential production with specialized inputs, such as Antràs and de Gortari (2020), Sposi, Yi and Zhang (2020), Johnson and Moxnes (2019), Yi (2003). None of them focuses on structural change.

\footnotetext{
${ }^{16} \mathrm{Pahl}$ and Timmer (2020) presents related evidence on the positive correlation between GVC participation and manufacturing productivity growth for a wide set of countries.
} 
While GVCs are typically thought of as involving only manufacturing, Sposi (2019) has shown that the importance of services as an intermediate good for manufacturing production tends to increase as countries develop. Hence, modeling GVCs could introduce several additional channels by which international trade can affect structural change.

\section{Trade and COVID-19}

While many of the issues we consider relate to long-run changes, and are thus unlikely to be affected much by cyclical factors, the size and nature of the COVID-19 shock has raised new questions about the scope for low-income countries to participate in trade in the near and medium term. In the near term, low-income countries, with their younger populations and more temperate climates, may end up being good sources of trading opportunities for middleand high-income countries. While investing in these trading opportunities is quite costly with the current travel bans and low levels of trade, it is likely that some newfound opportunities for trade may persist and have long run implications for their industrial structure.

In terms of long-run integration, the extreme volatility of the past 15 years may make more diversified supply sources and destination markets more valuable. COVID-19 is the latest in a string of global shocks - the Great Recession, Japan Earthquake, US-China Trade War. With the added concerns about climate change, firms are re-evaluating how their concentrated patterns of production or sales may expose them to risk. On the production side, there will be a tension between reshoring and redistributing activity across destinations. To the extent that low-income countries can produce certain commodities, such as personal protective equipment, this may hasten the development of new industries. Of course, with more diversified suppliers, the smaller scale of production combined with the higher logistic costs of low-income countries may ultimately lead to re-shoring.

COVID-19 also poses important macroeconomic and political risks to the development and integration path of low-income countries. With their reliance on commodity prices and pricier external debt, the fiscal positions of low-income countries have deteriorated. There is a key distributional aspect of COVID-19 that may enhance political instability and further weaken institutions. These changes may reduce trading and investment opportunities and shift the path of development.

\section{Summary}

In sum, to advance our understanding of international trade and structural change, it would be useful if the theoretical frameworks become more "micro", i.e., move to firm-level frame- 
works, study a broader and/or deeper set of sectors, and/or allow for global value chains. At the same time, embedding trade in models with richer dynamics and long-run growth would also strengthen the macro-analysis of structural transformation.

To better understand the challenges and opportunities for low-income countries, frameworks that recognize the particular features of their economic environments (e.g., pervasive informality, the scope for trade and foreign investment to raise productivity) and the challenges they face in overcoming trade barriers would be most useful. It is also important that the models be brought directly to the data to match observed transition paths. Disciplining these transition paths with the growing availability of micro data offers exciting opportunities.

Finally, the lessons of development from middle- and high-income countries may be less relevant given that those paths occurred when capital and trade flows where much smaller. As trade breaks the link between production and consumption at a moment and across time, we may need to rethink our markers for development.

\section{References}

Acemoglu, Daron, and Veronica Guerrieri. 2008. "Capital Deepening and Nonbalanced Economic Growth." Journal of Political Economy, 116(3): 467-498.

Albornoz, Facundo, Hector F. Calvo Pardo, Gregory Corcos, and Emanuel Ornelas. 2012. "Sequential Exporting." Journal of International Economics, 88(1): 17-31.

Albornoz, Facundo, Sebastián Fanelli, and Juan Carlos Hallak. 2016. "Survival in Export Markets." Journal of International Economics, 102: 262-281.

Alessandria, George, and Horag Choi. 2014. "Do Falling Iceberg Costs Explain Recent U.S. Export Growth?" Journal of International Economics, 94(2): 311-325.

Alessandria, George, and Oscar Avila. 2020a. "A Multi-Sector Model of Trade Adjustment Applied to Colombia." Unpublished Manuscript, University of Rochester.

Alessandria, George, and Oscar Avila. 2020b. "Trade Integration in Colombia: A Dynamic General Equilibrium Study with New Exporter Dynamics." Journal of Economic Dynamics and Control, 115: 103871. St. Louis Fed-JEDC-SCG-SNB-UniBern Conference: Disaggregate Data and Macroeconomic Models.

Alessandria, George, Costas Arkolakis, and Kim J. Ruhl. 2021. "Firm Dynamics and Trade." Annual Review of Economics. 
Alessandria, George, Horag Choi, and Dan Lu. 2017. "Trade integration and the trade balance in China." IMF Economic Review, 65(3): 633-674.

Alessandria, George, Horag Choi, and Kim J. Ruhl. forthcoming. "Trade Adjustment Dynamics and the Welfare Gains from Trade." Journal of International Economics.

Alessandria, George, Joseph P. Kaboski, and Virgiliu Midrigan. 2010. "Inventories, Lumpy Trade, and Large Devaluations." American Economic Review, 100(5): 2304-2339.

Alessandria, George, Sangeeta Pratap, and Vivian Z Yue. 2013. "Export Dynamics in Large Devaluations." Unpublished manuscript, University of Rochester.

Alfaro-Ureña, Alonso, Isabela Manelici, and Josè Vasquez. 2020. "The Effects of Joining Multinational Supply Chains: New Evidence from Firm-to-Firm Linkages." Unpublished Manuscript, UC Berkeley.

Amiti, Mary, and Josef Konings. 2007. "Trade Liberalization, Intermediate Inputs, and Productivity: Evidence from Indonesia." American Economic Review, 97(5): 1611-1638.

Antràs, Pol, and Alonso de Gortari. 2020. "On the Geography of Global Value Chains." Econometrica, 84(4): 1553-1598.

Atkin, David, Amit Khandelwal, and Adam Osman. 2017. "Exporting and Firm Performance: Evidence from a Randomized Experiment." Quarterly Journal of Economics, 132(2): 551-615.

Autor, David H., David Dorn, and Gordon H. Hanson. 2013. "The China Syndrome: Local Labor Market Effects of Import Competition in the United States." American Economic Review, 103(6): 2121-2168.

Baier, Scott L., and Jeffrey H. Bergstrand. 2007. "Do Free Trade Agreements Actually Increase Members' International Trade?" Journal of International Economics, 71(1): 7295.

Baier, Scott L., Jeffrey H. Bergstrand, and Michael Feng. 2014. "Economic Integration Agreements and the Margins of International Trade." Journal of International Economics, 93(2): 339-350.

Bernard, Andrew B., J. Bradford Jensen, Stephen J. Redding, and Peter K. Schott. 2018. "Global Firms." Journal of Economic Literature, 56(2): 565-619. 
Betts, Caroline, Rahul Giri, and Rubina Verma. 2017. "Trade, Reform, and Structural Transformation in South Korea." IMF Economic Review, 65(4): 745-791.

Blum, Bernardo S., Sebastian Claro, Kunal Dasgupta, and Ignatius J. Horstmann. 2019. "Inventory management, product quality, and cross-country income differences." American Economic Journal: Macroeconomics, 11(1): 338-88.

Bown, Chad P., and Meredith A. Crowley. 2014. "Emerging Economies, Trade Policy, and Macroeconomic Shocks." Journal of Development Economics, 111: 261 - 273. Special Issue: Imbalances in Economic Development.

Broda, Christian, Nuno Limao, and David E. Weinstein. 2008. "Optimal Tariffs and Market Power: The Evidence." American Economic Review, 98(5): 2032-65.

Brooks, Wyatt, and Alessandro Dovis. 2019. "Credit Market Frictions and Trade Liberalizations." Journal of Monetary Economics, 111: 32-47.

Bustos, Paula. 2011. "Trade Liberalization, Exports, and Technology Upgrading: Evidence on the Impact of MERCOSUR on Argentinian Firms." American Economic Review, 101(1): 304-340.

Cravino, Javier, and Sebastian Sotelo. 2019. "Trade-Induced Structural Change and the Skill Premium." American Economic Journal: Macroeconomics, 11(3): 289-326.

Crescenzi, Ricardo, and Nicola Limodio. 2020. "The Effect of Chinese FDI in Africa: Evidence From Ethiopia." Unpublished Manuscript, Bocconi University.

Das, Sanghamitra, Mark J. Roberts, and James R. Tybout. 2007. "Market Entry Costs, Producer Heterogeneity, and Export Dynamics." Econometrica, 75(3): 837-873.

De Loecker, Jan, and Pinelopi Koujianou Goldberg. 2014. "Firm Performance in a Global Market." Annual Review of Economics, 6: 201-227.

De Loecker, Jan, Pinelopi Goldberg, Amit Khandelwal, and Nina Pavcnik. 2016. "Prices, Markups, and Trade Reform." Econometrica, 84(2): 445-510.

Ding, Xiang, Theresa C. Fort, Stephen J. Redding, and Peter K. Schott. 2020. "Structural Change Within Versus Across Firms: Evidence from the United States." Unpublished manuscript, Princeton University.

Dix-Carneiro, Rafael, and Brian K. Kovak. 2017. "Trade Liberalization and Regional Dynamics." American Economic Review, 107(10): 2908-2946. 
Duarte, Margarida, and Diego Restuccia. 2020. "Relative Prices and Sectoral Productivity." Journal of the European Economic Association, 18(3): 1400-1443.

Erten, Bilge, and Jessica Leight. forthcoming. "Exporting out of Agriculture: The Impact of WTO Accession on Structural Transformation in China." Review of Economics and Statistics.

Erten, Bilge, Jessica Leight, and Fiona Tregenna. 2019. "Trade Liberalization and Local Labor Market Adjustment in South Africa." Journal of International Economics, 118: 448-467.

Fajgelbaum, Pablo, Gene M. Grossman, and Elhanan Helpman. 2011. "Income Distribution, Product Quality, and International Trade." Journal of Political Economy, 119(4): 721-765.

Fieler, Ana Cecília. 2011. "Nonhomotheticity and Bilateral Trade: Evidence and a Quantitative Explanation." Econometrica, 79(4): 1069-1101.

Goldberg, Pinelopi Koujianou, Amit Kumar Khandelwal, Nina Pavcnik, and Petia Topalova. 2010. "Imported Intermediate Inputs and Domestic Product Growth: Evidence from India." Quarterly Journal of Economics, 125(4): 1727-1767.

Grossi, Julia Cajal, Rocco Macciavello, and Guillermo Noguera. 2020. "International Buyers' Sourcing and Suppliers' Markups in Bangladeshi Garmets." Unpublished Manuscript, London School of Economics.

Hallak, Juan Carlos, and Jagadeesh Sivadasan. 2013. "Product and Process Productivity: Implications for Quality Choice and Conditional Exporter Premia." Journal of International Economics, 91(1): 53-67.

Halpern, Lázló, Miklós Koren, and Adam Szeidl. 2015. "Imported Inputs and Productivity." American Economic Review, 105(12): 3660-3703.

Herrendorf, Berthold, Richard Rogerson, and Akos Valentinyi. 2014. "Growth and Structural Transformation." In Handbook of Economic Growth, Volume 2B. Amsterdam:Elsevier B.V.

Hoekman, Bernard, and Alessandro Nicita. 2011. "Trade Policy, Trade Costs, and Developing Country Trade." World Development, 39(12): 2069 - 2079.

Irwin, Douglas A. 2019. "Does Trade Reform Promote Economic Growth? A Review of Recent Evidence." NBER Working Paper No. 25927. 
Javorcik, Beata Smarzynska. 2004. "Does Foreign Direct Investment Increase the Productivity of Domestic Firms? In Search of Spillovers Through Backward Linkages." American Economic Review, 94(3): 605-627.

Johnson, Robert C., and Andreas Moxnes. 2019. "GVCs and Trade Elasticities with Multistage Production." NBER Working Paper 26018.

Johnson, Robert C., and Guillermo Noguera. 2017. "A Portrait of Trade in ValueAdded over Four Decades." The Review of Economics and Statistics, 99(5): 896-911.

Jung, Benjamin. 2012. "Gradualism and Dynamic Trade Sdjustment: Revisiting the ProTrade Effect of Free Trade Agreements." Economics Letters, 115(1): 63-66.

Kee, Hiau Looi. 2015. "Local Intermediate Inputs and the Shared Supplier Spillovers of Foreign Direct Investment." Journal of Development Economics, 1(12): 56-71.

Kee, Hiau Looi, Alessandro Nicita, and Marcelo Olarreaga. 2009. "Estimating Trade Restrictiveness Indices*." The Economic Journal, 119(534): 172-199.

Kehoe, Timothy, Kim Ruhl, and Joseph Steinberg. 2018. "Global Imbalances and Structural Change in the United States." Journal of Political Economy, 126(2): 761-796.

Khan, Shafaat Y., and Armen Khederlarian. 2020. "Inventories, Input Costs and Productivity Gains from Trade Liberalizations." Unpublished manuscript, University of Rochester.

Kohn, David, Fernando Leibovici, and Michal Szkup. 2016. "Financial Frictions and New Exporter Dynamics." International Economic Review, 57(2): 453-486.

Kropf, Andreas, and Philip Sauré. 2014. "Fixed Costs per Shipment." Journal of International Economics, 92(1): 166-184.

Leibovici, Fernando. 2018. "Financial Development and International Trade." Unpublished manuscript, Federal Reserve Bank of St. Louis.

Lewis, Logan, Ryan Monarch, Michael Sposi, and Jing Zhang. 2020. "Structural Change and Global Trade." Unpublished manuscript, The Federal Reserve Board.

Lu, Yi, Zhigang Tao, and Lianming Zhu. 2017. "Identifying FDI Spillovers." Journal of International Economics, 107: 75-90. 
Matsuyama, Kiminori. 2009. "Structural Change in an Interdependent World: A Global View of Manufacturing Decline." Journal of the European Economic Association, 7(23): $478-486$.

McCaig, Brian. 2011. "Exporting Out of Poverty: Provincial Poverty in Vietnam and US Market Access." Journal of International Economics, 85(1): 102-113.

McCaig, Brian, and Margaret McMillan. 2020. "Trade liberalization and Labor Market Adjustment in Botswana." Journal of African Economies, 29(3): 236-270.

McCaig, Brian, and Nina Pavcnik. 2018. "Export Markets and Labor Allocation in a Low-Income Country." American Economic Review, 108(7): 1899-1941.

McCaig, Brian, Nina Pavcnik, and Woan Fung Wong. 2020. "Export Markets and Long-Run Industry Adjustment: State, Private, and Foreign Firms in Vietnam." Unpublished manuscript, Wilfrid Laurier University.

Menezes-Filho, Naércio Aquino, and Marc-Andreas Muendler. 2011. "Labor Reallocation in Response to Trade Reform." NBER Working Paper No. 17372.

Merga, Roman. 2019. "Real Exchange Rate Uncertainty Matters: Trade, Shipping Lags, and Default." Unpublished manuscript, University of Rochester.

Mix, Carter. 2020. "Technology, Geography, and Trade Over Time: The Dynamic Effects of Changing Trade Policy." Board of Governors of the Federal Reserve System: International Finance Discussion Papers Number 1304.

Morales, Eduardo, Gloria Sheu, and Andrés Zahler. 2019. "Extended Gravity." The Review of Economic Studies, 86(6): 2668-2712.

Nadais, Ana. 2017. "Are International Fixed Ordering Costs Higher Than Domestic? An Inventory Approach." Unpublished manuscript, University of Rochester.

Pahl, Stefan, and Marcel P. Timmer. 2020. "Do Global Value Chains Enhance Economic Upgrading? A Long View." The Journal of Development Studies, 56(9): 1683-1705.

Reyes-Heroloes, Ricardo. 2016. "The Role of Trade Costs in the Surge of Trade Imbalances." Unpublished manuscript, The Federal Reserve Board.

Roberts, Mark J., and James R. Tybout. 1997. "The Decision to Export in Colombia: An Empirical Model of Entry with Sunk Costs." American Economic Review, 87(4): 545564 . 
Rodriguez, Francisco, and Dani Rodrik. 2001. "Trade Policy and Economic Growth: A Skeptic's Guide to the Cross-National Evidence." In NBER Macroeconomics Annual 2000, Volume 15. NBER Chapters, 261-338. National Bureau of Economic Research, Inc.

Ruhl, Kim J., and Jonathan L. Willis. 2017. "New Exporter Dynamics." International Economic Review, 58(3): 703-726.

Sposi, Michael. 2019. "Evolving Comparative Advantage, Sectoral Linkages, and Structural Change." Journal of Monetary Economics, 103: 73-87.

Sposi, Michael, Kei-Mu Yi, and Jing Zhang. 2020. "Trade Integration, Global Value Chains, and Capial Accumulation." NBER Working Paper 28087.

Steinberg, Joseph. 2020. "Export Market Penetration Dynamics." Unpublished manuscript, University of Toronto.

Swiecki, Tomasz. 2017. "Determinants of Structural Change." Review of Economic Dynamics, 24: 95-131.

Teignier, Marc. 2018. "The Role of Trade in Structural Transformation." Journal of Development Economics, 130: 45-65.

Topalova, Petia. 2010. "Factor Immobility and Regional Impacts of Trade Liberalization: Evidence on Poverty from India." American Economic Journal: Applied Economics, 2(4): $1-41$.

Topalova, Petia, and Amit Khandelwal. 2011. "Trade Liberalization and Firm Productivity: The Case of India." The Review of Economics and Statistics, 93(3): 995-1009.

Uy, Timothy, Kei-Mu Yi, and Jing Zhang. 2013. "Structural Change in an Open Economy." Journal of Monetary Economics, 60: 667-682.

Verhoogen, Eric A. 2008. "Trade, Quality Upgrading, and Wage Inequality in the Mexican Manufacturing Sector." The Quarterly Journal of Economics, 123(2): 489-530.

Waugh, Michael. 2010. "International Trade and Income Differences." American Economic Review, 100(5): 2093-2124.

World Bank. 2020. Trading for Development In the Age of Global Value Chains. Washington, DC:International Bank for Reconstruction and Development.

Yi, Kei-Mu. 2003. "Can Vertical Specialization Explain the Growth of World Trade?" Journal of Political Economy, 111(1): 52-102. 